\title{
Role of Anti-mullerian Hormone (AMH), As A Prediction of Clinical Pregnancy Outcome in Women with Polycystic Ovarian Syndrome with Sub Fertility
}

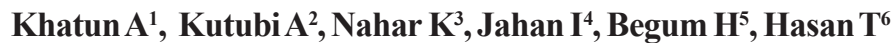

Conflict of Interest: There is no conflict of interest declared by all authors.

Contribution to authors: AK, FD \& $\mathrm{AH}$ were contributed, from preparation of protocol up to research works. AK \& MR were prepared the manuscript

Received: 17 May 2017

Accepted: $1^{\text {st }}$ June 2017 www.banglajol.info/index.php/JSSMC

Key Words:

Infertility, PCOS, anti-mullerian hormone, (Obs \& Gynae); OPD

\section{Abstract}

Background: Anti-mullerian hormone (AMH) in largely expressed throughout folliculogenisis (by granulosa cells in ovarian follicles) but highest in pre-antral and small antral steges $(<4 \mathrm{~mm})$ drameter of development.

Objective: To analyse the usefulness of plasma anti-mullerian hormone (AMH) measurement as a test for assessing ovarian reserve in Polycystic ovary syndrome with sub fertility,

Methodology: Women with PCOS and sub fertility, were included in this study with age group 18-35yrs. This Prospetive cohort study done in 30 cases in ShSMC with purposive randomized sampling, from January 2015 to December 2015. Serum, plasma \& for evaluation of PCOS, preferably TV-USG was done.

Result: In this study we analyze 30 serum samples from patient aged between 18-35 years and transvaginal ultrasonography was done simultaneously. Mean age group of my patient was $25.2 \pm 4.7$ years which correlates with AMH level in PCOS which is statistically significant $(p<0.001)$. Mean level of AMH is $5.7 \pm 4.9 \mathrm{mg} / \mathrm{ml}$ which is also correlate with transvaginal USG scan with the feature of PCOS $(p<.0 .001)$. More than $50 \%$ woman presents with features of subfertility with PCOS and 46.7\% are normal ovaries. Mean menstrual day 7.6 (4-12 days) which have a good linear correlation with irregularities of menstrual cycle and $\operatorname{PCOS}(p<0.05)$.

Conclusion: To conclude AMH appears to have a major inhibiting role during folliculogenesis, which may contribute to anovulation in PCOS. The reason for the raised AMH in PCOS may give clues as to the mechanism os anovulation.

[J Shaheed Suhrawardy Med Coll 2017; 9(1): 3-5] DOI: http://dx.doi.org/10.3329/jssmc.v9i1.37250

\section{Introduction}

Anti-mullerian hormone (AMH) in largely expressed throughout folliculogenesis (by granulosa cells in ovarian follicles) but highest in pre-antral and small antral steges $(<4 \mathrm{~mm})$ diameter of development. Serum AMH level may represent the quality and quantity of ovarian follicular

1. Dr. Ashia Khatun, Associate Professor, Department of Obst. \& Gynae, Shaheed Suhrawardy Medical College, Dhaka

2. Dr. Afroza Kutubi, Associate Professor, Department of Obst. \& Gynae, Dhaka Medical College

3. Dr. Khairun Nahar, Associate Professor, Department of Obst. \& Gynae, BSMMU, Dhaka

4. Dr. Israt Jahan, Assistant Professor, Department of Obst. \& Gynae, Shaheed Suhrawardy Medical College, Dhaka

5. Dr. Hasina Begum, Junior Consultant, Department of Obst. \& Gynae, Shaheed Suhrawardy Medical College \& Hospital, Dhaka

6. Dr. Tahmina Hassan, Medical Officer, Department of Obst. \& Gynae, Shaheed Suhrawardy Medical College \& Hospital, Dhaka

Corresponding Author: Dr. Ashia Khatun, Assistant Professor (Gynae \& Obs), Shaheed Suhrawardy Medical College, Dhaka, SherE-Bangla Nagar, Dhaka-1207. Email- drashiakhatun715@gmail.com pool. ${ }^{1}$ AMH-production decreases and then stops as follicles grow. There is almost no AMH made in follicles over- $8 \mathrm{~mm} .^{2}$ AMH-blood level are thought to reflect the size of the remaining egg supply or "ovarian reserve" and can be measured any times of menstrual cycle. ${ }^{3} \mathrm{AMH}$ is a focus of interest in polycystic ovary syndrome (PCOS), there appear two groups of women with PCOS who can be distinguished by their AMH level. ${ }^{4} \mathrm{AMH}$ is directly related to the number of Oocyte that are suitable at IVF, its value is in identificat ion of women likely to over responds and thus be at risk of ovarian hyperstimultion syndrome and conversely, women where a poor response in predicted, to help manage expectations. ${ }^{5} \mathrm{AMH}$-is bear discriminator than FSH. AMH is frequently to as reflecting the ovarian response meaning the number of Follicles that can be sensitized to grown by the administration of FSH. ${ }^{6}$ The term "Overran reserve" is also used, perhaps more accurately, to mean the post of primodial non-growing 
follicles within the ovary thus AMH-can be correctly surge to reflect the ovarian reserve. ${ }^{7} \mathrm{As} \mathrm{AMH}$ is produced by small follicles whose numbers reflect the primordial pool, concentrations decline with age in adult women. ${ }^{8}$ The production of AMH by small antral follicles clearly indicates that $\mathrm{AMH}$ production is likely to be FSHregulated, as these follicles are regulated by $\mathrm{FSH}^{9}$

\section{Methodology}

This prospective cohort study was conducted at the infertility clinic in Shaheed Suhrawardy Medical College Hospital, Dhaka, Bangladesh. Thirty cases were taken by purposive randomized sampling technique. Women with PCOS and primary subfertility were included in this study with age 18-35 yrs and transvaginal ultrasonography was done simultaneously. Blood sample was taken for measurement of AMH level in serum. Patient with significant hyperprolactinemia, abnormal thyroid function tests, and congenital adrenal hyperplasia were excluded from this study. The data analysis was done by SPSS (version 17.0) program. The results are shown in graphs $\&$ tables.

\section{Results}

In this study we analyze 30 serum samples from patient aged between 18-35 years and transvaginal ultrasonography was done simultaneously. Mean age group of patient was $25.2 \pm 4.7$ years which correlates with AMH level in PCOS, which is statistically significant $(p<0.001)$. Mean level of AMH is $5.7 \pm 4.9 \mathrm{mg} /$ $\mathrm{ml}$ which is also correlate with transvaginal USG scan with the feature of PCOS $(\mathrm{p}<.0 .001)$. More than $50 \%$ woman presents with features of subfertility with PCOS and $46.7 \%$ are normal ovaries. Mean menstrual day 7.6 (4-12 days) which have a good linear correlation with irregularities of menstrual cycle and PCOS $(\mathrm{p}<0.05)$. Mean of marriage 6.6 \pm 3.3 years (range 1.5-15 years). So, serum AMH assessment could predict the good or poor ovarian reserve for management of PCOS women with sub fertility and in vitro fertilization.

Table-1

Age distribution among the patients with PCOS

\begin{tabular}{lcccc} 
Age & Frequency & Percent & Mean \pm SD & P-value \\
\hline $18-25$ years & 19 & 63.3 & $25.2 \pm 4.7$ & $\mathrm{P}<0.001$ \\
$26-35$ years & 11 & 36.7 & & \\
\hline Total & 30 & 100.0 & & \\
\hline
\end{tabular}

Table-II

\begin{tabular}{|c|c|c|c|}
\hline \multicolumn{4}{|c|}{ Association with menstrual history and provisional diagnosis } \\
\hline $\begin{array}{l}\text { Association with menstrual history and } \\
\text { provisional diagnosis }\end{array}$ & $\begin{array}{c}\text { Regular } \\
\text { means }\end{array}$ & $\begin{array}{l}\text { Irregular } \\
\text { means }\end{array}$ & P value \\
\hline Primary infertility & 11 & 7 & 0.09 \\
\hline Secondary infertility & 4 & 1 & \\
\hline Primary infertility with PCOS & 1 & 5 & \\
\hline Secondary infertility with PCOS & 0 & 1 & \\
\hline Total & 16 & 14 & \\
\hline
\end{tabular}

Table-III

\begin{tabular}{|c|c|c|c|}
\hline \multicolumn{4}{|c|}{ Association with USG and AMH } \\
\hline Association with USG and AMH & Mean & Standard Deviation & $\mathrm{P}$ value \\
\hline $\mathrm{AMH}$ & 5.68 & 4.90 & 0.001 \\
\hline USG & 1.57 & 0.57 & \\
\hline
\end{tabular}

Table-IV

Association with menstrual history and AMH

\begin{tabular}{lccc} 
Association with menstrual history and AMH & Mean (day) & Standard Deviation & P value \\
\hline Menstrual history & 7.60 & 3.33 & 0.005 \\
AMH & 5.68 & 4.90 & \\
\hline
\end{tabular}




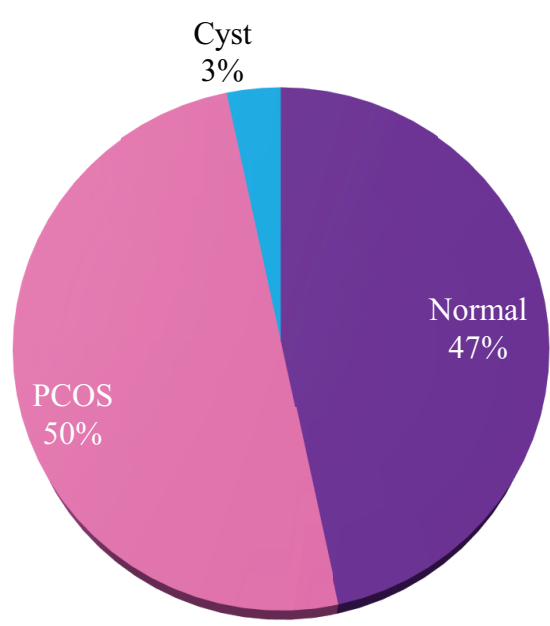

Figure-1: Transvaginal USG scan result of the ovarian volume

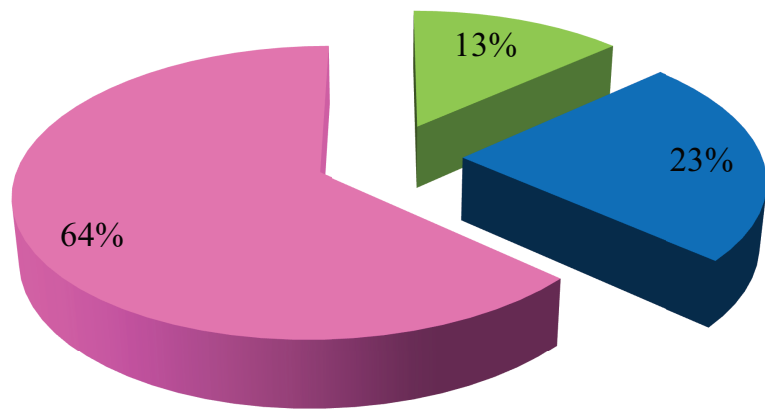

- Lowest level

- Normal level

- Highest Level

Figure-2: AMH level in serum

\section{Discussion}

Many studies published in recent years have demonstrated that the concentration of AMH is 3-4 times higher in patients affected by PCOS than in patients age and other hormonal test, such as FSH, because it is influence by menstrual cycle. Identification of PCOS by means of invasive test such as transvaginal ultrasonography for follicular count and residual ovarian capacity. In my study: We also compare our values with reported in literature, comparing the value that are obtained with those other literature, it can be seen that the average values of controls $(1.5-3 \mathrm{mg} / \mathrm{dl})$ are lower than those in patient with PCOS, confirming the validity of the test (3$19.5 \mathrm{mg} / \mathrm{dl}$ ) as an indicator of the syndrome (PCOS). Other hormonal evoluation also done like LH, S.TSH, S.T.

\section{Conclusion}

AMH gives an evaluation tools in either reduced and elevated levels in PCOS women. AMH is considered as a useful test to study folliculo genesis and ovarian potential in various situations of fertility and for identification of PCOS. To avoid the possibility of subjecting patients at risk of ineffective assisted reproductive technology and using hormonal stimulation or in vitro embryo transfer needs careful clinical assessment.

\section{References}

1. Broekmans F J, Soules M R \& Fauser B C. Ovarian aging: mechanisms and clinical consequence. Endocrine Review. 2009; 30:465-93.

2. A. La Marca, A. Volpe. Anti-Mullerian Hormone (AMH) in female reproduction: Is measurement of circulating $\mathrm{AMH}$ a useful tool? Clin Endoccrinol. 2006; 64(6): 603-10.

3. Tremellen K P, Kolo M, Gilmore A \& Lekamge D N. Antimullerian hormone as a marker of ovarian reserve. Australian and New Zealand Journal of Obstetrics and Gynecology. 2005; 45(1): 20-24.

4. Laura Pellat, Suman Rice \& Helen D Mason. Anti-Mullerian hormone and polycystic ovary syndrome: a mountain too high? Journal of Reproduction. 2010; 139: 825-33.

5. Van Rooij, IAJ, Brokemns, F.J.M to velole, ER, et al. Serum anti-mullerian hormone level's an novel measure of ovarian reserve. Human Reproduction. 2002; 17: 3065-71.

6. Nelson, SM, yates, R.N q Fleming R. (2007). Serum antimullerian hormone and FSH: prediction of live birth and extreme response in stimulated cycle-implications for individual of therapy. Human Reproduction, 22,2414-21.

7. Hansan, KR, Hodnett, GM. Knowtlon, N et al (2011) completion of ovarian reason tests with histological determined primordial follicles number, Fertility and sterility, 95, m 170-75

8. Van Rooij, I.A.J., Brokemans F.J.M., Schefter, G.J et al (2005) serum antimulberan hormone levels best reflect the reproductive decline with age in normal woman with proven.

9. Fertility: Longitudinal study: Fertility and sterility, 83, 979-87. 